\title{
Interactive Role of Silicon and Plant-Rhizobacteria Mitigating Abiotic Stresses: A New Approach for Sustainable Agriculture and Climate Change
}

\author{
Krishan K. Verma ${ }^{1,+}{ }^{\oplus}$, Xiu-Peng Song ${ }^{1,+}{ }^{\dagger}$, Dong-Mei Li ${ }^{1}$, Munna Singh ${ }^{2}$, Vishnu D. Rajput ${ }^{3} \mathbb{D}$,

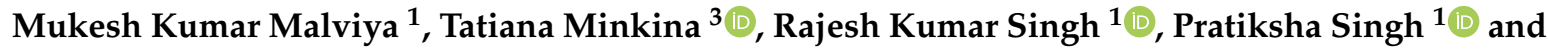 \\ Yang-Rui Li ${ }^{1, * \mathbb{D}}$ \\ 1 Key Laboratory of Sugarcane Biotechnology and Genetic Improvement (Guangxi), Ministry of Agriculture \\ and Rural Affairs/Guangxi Key Laboratory of Sugarcane Genetic Improvement/Sugarcane Research Institute, \\ Guangxi Academy of Agricultural Sciences, Nanning 530007, China; drvermakishan@gmail.com (K.K.V.); \\ xiupengsong@gxaas.net (X.-P.S.); lidongmei@gxaas.net (D.-M.L.); mkshmalviya@yahoo.com (M.K.M.); \\ rajeshsingh999@gmail.com (R.K.S.); singh.pratiksha23@gmail.com (P.S.) \\ 2 Department of Botany, University of Lucknow, Lucknow 226007, India; drmunnasingh@yahoo.com \\ 3 Academy of Biology and Biotechnology, Southern Federal University, Rostov-on-Don 344006, Russia; \\ rajput.vishnu@gmail.com (V.D.R.); tminkina@mail.ru (T.M.) \\ * Correspondence: liyr@gxaas.net; Tel.: +86-138-0788-3389 \\ + These authors have contributed equally to this work.
}

Received: 9 July 2020; Accepted: 17 August 2020; Published: 19 August 2020

\begin{abstract}
Abiotic stresses are the major constraints in agricultural crop production across the globe. The use of some plant-microbe interactions are established as an environment friendly way of enhancing crop productivity, and improving plant development and tolerance to abiotic stresses by direct or indirect mechanisms. Silicon $(\mathrm{Si})$ can also stimulate plant growth and mitigate environmental stresses, and it is not detrimental to plants and is devoid of environmental contamination even if applied in excess quantity. In the present review, we elaborate the interactive application of $\mathrm{Si}$ and plant growth promoting rhizobacteria (PGPRs) as an ecologically sound practice to increase the plant growth rate in unfavorable situations, in the presence of abiotic stresses. Experiments investigating the combined use of $\mathrm{Si}$ and PGPRs on plants to cope with abiotic stresses can be helpful in the future for agricultural sustainability.
\end{abstract}

Keywords: abiotic stresses; mitigation; PGPRs; plant hormones; plant growth promotion; silicon

\section{Introduction}

The global population is presently around 7.7 billion and may further swell in the next few years to become 10 billion by 2050 [1-3]. Population ballooning severely impairs the land holding capacity, particularly in Asian countries [2]. Increasing anthropogenic activities, such as the release of greenhouse gases, result in heating of the natural environment. Perturbations in climatic conditions, in turn, negatively impact food security, jeopardizing food availability and the livelihood of people [4]. Feeding such a large population is an evolving challenge for the agricultural sector and scientists [5]. Sustainable agricultural production is integral to food security; abiotic stressors, which are either the consequence of or are aggravated by climatic elements, attribute to about a 50\% loss in agriculture [6]. Physical and chemical environmental factors, such as light, temperature, moisture, salinity, nutrient availability, presence of industrial and agrochemical contaminants in soil and water resources, etc., impact the growth rate and productivity. The osmotic stress caused by abiotic factors disrupts ion 
distribution and cell homeostasis in plants. Abiotic stresses also interact with biotic stresses, making the plant more susceptible to infestations $[7,8]$.

Multitudes of microbial forms reside in the plant root, developing complicated microbial associations that affect plant development and production through metabolic characteristic traits and plant associations $[9,10]$. Variations in the morphology of plant-associated bacteria in the rhizospheric region towards the assortment of groups that are acclimated to environmental variables facilitate adaptations to environmental stresses to support better health and tolerance in plants [11]. Some of the beneficial soil bacteria, such as plant growth-promoting rhizobacteria (PGPRs), colonize the roots of plants (rhizosphere) and enhance plant performance [12] and yield [13]. PGPRs are not only linked with the roots to exert significant responses on plant growth but also have significant consequences in regulating phytopathogens $[14,15]$. They are also involved in improvement of the crop yield and soil profile by promoting the formation of soil aggregates and pores [16].

The employment of silicon ( $\mathrm{Si}$ ) in agricultural activities is another potential element for the mitigation of abiotic stresses in crop plants [2,17]. Silicon is listed as the eighth most common element in nature and the second most common element found in soil after molecular oxygen [18]. The element is found as monosilicic acid $\left(\mathrm{H}_{4} \mathrm{SiO}_{4}\right)$ in soil; it is an uncharged molecule at $\mathrm{pH}<9$ [19] and may get ionized as silicate ions, i.e., $(\mathrm{OH})_{3} \mathrm{SiO}$, in higher $\mathrm{pH}(>9)$. Si gets reduced in the soil from the weathering of silicate-containing minerals [20]. The dissolved content of Si varies significantly depending on the types of minerals and surrounding variables [21] as most of the soil is rich in Si. However, the availability of $\mathrm{Si}$ in plants is linked with soil types and seasonal environmental characteristics. Silicon has a strong affinity with $\mathrm{O}_{2}$ to generate silicon dioxide $\left(\mathrm{SiO}_{2}\right)$, the most common form of $\mathrm{Si}$, which constitutes around $50 \%$ of the soil mass [18,22]. The predominant form of $\mathrm{Si}$ in mineral soils includes $\mathrm{SiO}_{2}$ and primary or secondary silicate minerals having metals, such as $\mathrm{Al}$ (aluminosilicates) and $\mathrm{Mg}$ [23].

Silicon also exists in many irregular structures of biogenic origin, i.e., phytoliths and silica-enriched plants [24], which constitutes about 1-3\% of the overall Si pool of soil [25,26]. It extends beneficial effects on plants' fitness, performance, and productivity by mitigating abiotic and biotic stresses [17,27-31] along with the regulation of defense signaling pathways [32] to synergically upregulate tolerance against stress.

Both PGPRs and Si have an independent capacity to mitigate environmental stresses like salinity, water deficit, heavy metal toxicity, and nutrient deficiency $[13,17,29]$. Nearly $1-2 \%$ of cultivated land is affected by salinity [33], while a water deficit affects nearly 30\% of the global land area. Both these stresses share several common characteristics on agriculture crop productivity [34]. Heavy metal contamination, industrial waste discharge, and pesticides are increasingly polluting the ecosystem and, thereby, plant physiology and well-being [2,35]. The present review deals with information pertaining to the mitigation of various stress factors through the application of $\mathrm{Si}$ and growth-promoting microbes and comparatively presents the functions by which mitigation occurs (Figures 1 and 2). The information generated from the combined use of Si and PGPRs from this review could be very beneficial for environmental protection and agricultural sustainability. 


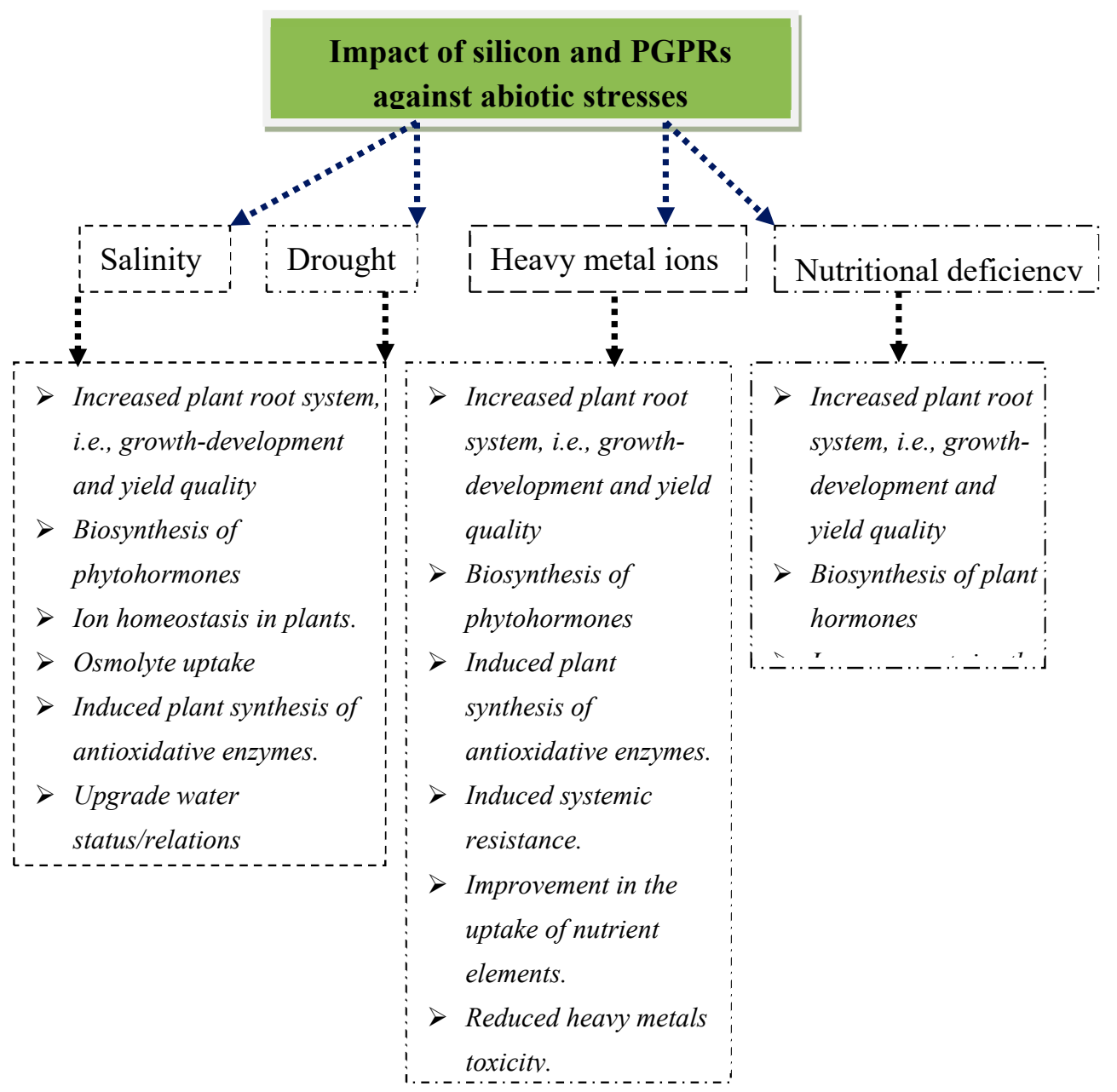

Figure 1. The multiple functions of silicon and plant growth promoting rhizobacteria (PGPRs) alleviate abiotic stresses in plants [17,29,36-44].

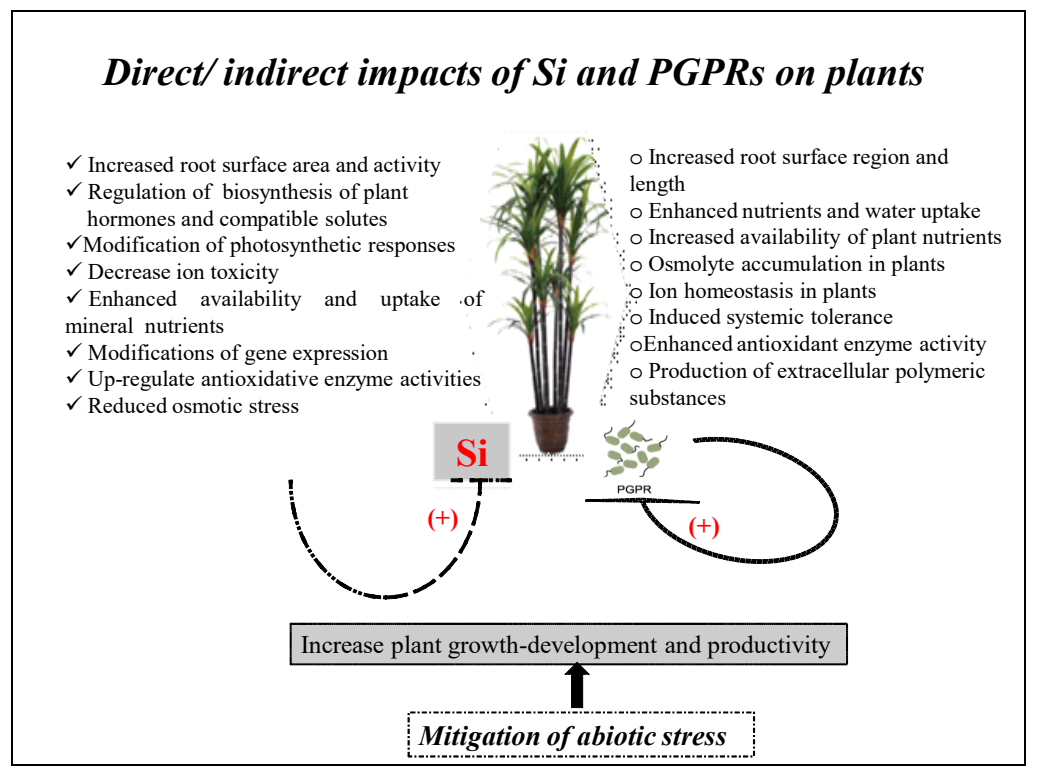

Figure 2. The mechanisms by which $\mathrm{Si}$ and PGPRs mitigate abiotic stress in plants. 


\section{Role of PGPRs and Si-Mediated Mitigation Against Stress in Plants}

The combined use of $\mathrm{Si}$ and PGPRs in cultivating agricultural crops has been accepted as a sustainable strategy in mitigating salinity [45] and water stress [46,47]. PGPRs may enhance biological $\mathrm{N}_{2}$ fixation, biosynthesis of phytohormones, and nutrient solubilization to sustain plant growth and development, with the ability to resist environmental stresses [44] (Figures 1 and 2, Tables 1 and 2). The pioneering work related with synergistic action and an improved technique for the mitigation of saline stress in Vigna radiata though combinatorial application of Si and PGPRs was studied [45,48]. In this section, the mechanisms and functions of PGPRs and Si-mediated stress tolerance in agricultural crop plants are discussed.

Table 1. Role of silicon on the growth, physiology, and biochemistry of plants.

\begin{tabular}{|c|c|c|c|c|c|}
\hline Growth Condition & Plant/ Cultivars & Source of $\mathrm{Si}$ & Variables & $\begin{array}{l}\text { Effect of } S i \\
\text { with Stress }\end{array}$ & Reference \\
\hline \multirow[t]{33}{*}{ Drought } & \multirow[t]{10}{*}{ Saccharum officinarum } & \multirow[t]{10}{*}{ Calcium-metasilicate } & Net $\mathrm{CO}_{2}$ assimilation & + & \multirow[t]{10}{*}[17,29-31]{} \\
\hline & & & Stomatal conductance & + & \\
\hline & & & Transpiration rate & + & \\
\hline & & & Photosynthesis pigments & + & \\
\hline & & & RWC $(\%)$ & + & \\
\hline & & & CAT & + & \\
\hline & & & POD & + & \\
\hline & & & SOD & + & \\
\hline & & & Plant hormones & + & \\
\hline & & & $\left(\mathrm{ABA}, \mathrm{IAA}\right.$, and $\left.\mathrm{GA}_{3}\right)$ & + & \\
\hline & \multirow[t]{10}{*}{$\begin{array}{c}\text { Strawberry } \\
\text { (Fragaria } x \text { ananassa } \\
\text { 'Camarosa') }\end{array}$} & \multirow[t]{10}{*}{ Potassium silicate } & Leaf area-number & no effect & \multirow[t]{10}{*}{ [49] } \\
\hline & & & Petiole length & + & \\
\hline & & & Electrolyte leakage (\%) & no effect & \\
\hline & & & Chlorophyll index & + & \\
\hline & & & $F v / F m$ & + & \\
\hline & & & $P_{N}$ & + & \\
\hline & & & $\mathrm{E}$ & + & \\
\hline & & & WUE & + & \\
\hline & & & Proline content & + & \\
\hline & & & Shoot/ root FM/DM & + & \\
\hline & \multirow[t]{10}{*}{ Solanum lycopersicum } & \multirow[t]{10}{*}{ Potassium silicate } & $\mathrm{EC}(\%)$ & + & \multirow[t]{10}{*}[50]{} \\
\hline & & & Root hydraulic conductance & + & \\
\hline & & & Photosynthesis & + & \\
\hline & & & Transpiration & + & \\
\hline & & & MDA & + & \\
\hline & & & $\mathrm{H}_{2} \mathrm{O}_{2}$ & + & \\
\hline & & & CAT activity & + & \\
\hline & & & SOD activity & + & \\
\hline & & & Ascorbic acid & + & \\
\hline & & & Reduced GSH activity & + & \\
\hline & \multirow{3}{*}{$\begin{array}{c}\text { Triticum aestivum and } \\
\text { Zea mays }\end{array}$} & \multirow{3}{*}{$\begin{array}{l}\text { Sodium and calcium } \\
\text { silicate }\end{array}$} & Growth and yield traits & + & \multirow[t]{3}{*}[51,52]{} \\
\hline & & & Chlorophyll fluorescence & + & \\
\hline & & & Leaf gas exchange & + & \\
\hline \multirow[t]{16}{*}{ Salinity } & \multirow[t]{11}{*}{ Cucumis sativus } & \multirow[t]{11}{*}{ Calcium silicate } & Total DM & + & \multirow[t]{11}{*}{ [53] } \\
\hline & & & Root EC (\%) & + & \\
\hline & & & Protein content & + & \\
\hline & & & MDA & + & \\
\hline & & & $\mathrm{H}_{2} \mathrm{O}_{2}$ content & + & \\
\hline & & & CAT activity & - & \\
\hline & & & APx activity & + & \\
\hline & & & GPx activity & + & \\
\hline & & & SOD activity & + & \\
\hline & & & GR activity & + & \\
\hline & & & DHAR activity & + & \\
\hline & \multirow[t]{5}{*}{ Oryza sativa } & \multirow[t]{5}{*}{ Sodium silicate } & Dry mass & + & \multirow[t]{5}{*}{ [54] } \\
\hline & & & $\mathrm{Na}^{+}$content & + & \\
\hline & & & $\mathrm{Na}+$ influx and efflux & - & \\
\hline & & & Transpiration rate & + & \\
\hline & & & Apoplastic bypass flow & + & \\
\hline
\end{tabular}


Table 1. Cont

\begin{tabular}{|c|c|c|c|c|c|}
\hline Growth Condition & Plant/ Cultivars & Source of $\mathrm{Si}$ & Variables & $\begin{array}{l}\text { Effect of } S i \\
\text { with Stress }\end{array}$ & Reference \\
\hline & Vigna radiata & $\begin{array}{l}\text { Potassium silicate } \\
\text { and PGPR strains ( } E . \\
\text { cloacae and } B . \\
\text { drentensis) }\end{array}$ & Growth traits & + & [45] \\
\hline & & & Shoot \& root fresh/ dry mass & + & \\
\hline & & & Green pigments & + & \\
\hline & & & Gas exchange & + & \\
\hline & & & Salt tolerance index & + & \\
\hline & & & Crop output & + & \\
\hline & Sorghum bicolor & Sodium silicate & Total dry mass & + & [55] \\
\hline & & & Photosynthetic pigments & + & \\
\hline & & & Root $\mathrm{Na}^{+}$and $\mathrm{K}^{+}$content & - & \\
\hline & & & Total polyamine content & + & \\
\hline & & & Total ACC content & + & \\
\hline & Oryza sativa & Silicic acid & Total no. of tillers & - & [56] \\
\hline & & & Leaf area & - & \\
\hline & & & Dry mass & - & \\
\hline & & & Chlorophyll content & - & \\
\hline & & & Proline content & + & \\
\hline & & & SOD activity & + & \\
\hline \multirow[t]{10}{*}{ Osmotic } & Sorghum bicolor & Sodium silicate & Photosynthetic responses & + & [57] \\
\hline & & & Root hydraulic resistance & + & \\
\hline & & & Plant dry mass & + & \\
\hline & Solanum lycopersicum & Potassium silicate & Leaf gas exchange & + & [50] \\
\hline & & & LWC & + & \\
\hline & & & Root EC & + & \\
\hline & & & $\mathrm{MDA}, \mathrm{H}_{2} \mathrm{O}_{2}$ & + & \\
\hline & & & Antioxidant enzymes & + & \\
\hline & & & Ascorbic acid content & + & \\
\hline & & & GSH activity & + & \\
\hline \multirow{5}{*}{ Cd Toxicity } & Oryza sativa & Sodium silicate & Total DM & + & [58] \\
\hline & & & $\mathrm{H}_{2} \mathrm{O}_{2}$ content (leaf and root) & + & \\
\hline & & & Ascorbate content (leaf \& root) & + & \\
\hline & & & GSH content (leaf and root) & + & \\
\hline & & & NPT content (leaf and root) & + & \\
\hline \multirow[t]{5}{*}{ As Toxicity } & Oryza sativa & Sodium silicate & Photosynthesis & + & [59] \\
\hline & & & $g s$ & + & \\
\hline & & & $g \mathrm{~m}$ & + & \\
\hline & & & $\mathrm{Fv} / \mathrm{Fm}$ & no effect & \\
\hline & & & Vcmax and Jmax & " & \\
\hline \multirow{5}{*}{ Cu Toxicity } & Spartina densiflora & Potassium silicate & Shoot FM & $"$ & {$[60]$} \\
\hline & & & Root FM and RGR & + & \\
\hline & & & Leaf gas exchange & + & \\
\hline & & & Chlorophyll content & + & \\
\hline & & & Rubisco content & + & \\
\hline \multirow[t]{3}{*}{ Mn Toxicity } & Cucumis sativa & Sodium silicate & Shoot fresh and dry mass & + & {$[61,62]$} \\
\hline & & & Leaf Mn content & - & \\
\hline & & & $\mathrm{H}_{2} \mathrm{O}_{2}$ and GPx activity & + & \\
\hline \multirow[t]{3}{*}{ Al Toxicity } & Zea mays & Potassium silicate & Root size & + & [63] \\
\hline & & & Root citrate and malate exudation & - & \\
\hline & & & Root phenol exudation & - & \\
\hline \multirow[t]{6}{*}{$\mathrm{K}^{+}$Deficiency } & Sorghum bicolor & Sodium silicate & Total dry wt. & + & {$[64,65]$} \\
\hline & & & $\mathrm{CO}_{2}$ assimilation & + & \\
\hline & & & Protein content & + & \\
\hline & & & Green pigments & + & \\
\hline & & & $\begin{array}{l}\text { Leaf polyamine and arginine } \\
\text { content }\end{array}$ & + & \\
\hline & & & Antioxidant enzymes & + & \\
\hline
\end{tabular}


Table 2. Plant-rhizobacteria-mediated plant tolerance to abiotic stresses.

\begin{tabular}{|c|c|c|c|}
\hline Stress Condition & Plant/ Cultivar & Bacterial Inoculate & Reference \\
\hline Salinity & Phaseolus vulgaria & Azospirillum brasilense & {$[66]$} \\
\hline$"$ & Vicia faba & Enterobacter cloacae, Bacillus drentensis & {$[45]$} \\
\hline$"$ & Zea mays & $\begin{array}{c}\text { Pseudomonas syringae, } P \text {. fluorescens, } \\
\text { Enterobacter aerogenes }\end{array}$ & [67] \\
\hline$"$ & Arachis hypogaea & P. fluorescens & {$[68]$} \\
\hline$"$ & Lactuca sativa & Azospirillum & [69] \\
\hline$"$ & Lycopersicon esculentum & Achromobacter piechaudii & [70] \\
\hline$"$ & Triticum aestivum & $\begin{array}{c}\text { Aeromonas hydrophila/caviae, Bacillus } \\
\text { insolitus, Bacillus spp. }\end{array}$ & [71] \\
\hline " & Zea mays & Azospirillum & [72] \\
\hline$"$ & Cicer arietinum, Vicia faba & A. brasilense & [73] \\
\hline$"$ & Zea mays & Bacillus & [74] \\
\hline " & Vicia faba, Gossypium hirsutum & Pseudomonas & {$[75,76]$} \\
\hline Low water & $\begin{array}{c}\text { Lycopersicon esculentum, Capsicum } \\
\text { annuum }\end{array}$ & Achromobacter piechaudii & [77] \\
\hline " & Triticum aestivum & Azospirillum & [78] \\
\hline$"$ & Zea mays & Azospirillum brasilense & [79] \\
\hline " & Phaseolus vulgaris & Azospirillum brasilense & [80] \\
\hline Drying soil & Pisum sativum & Variovorax paradoxus & [81] \\
\hline Drying soil & Lactuca sativa & Bacillus & [82] \\
\hline $\begin{array}{l}\text { Osmotic stress } \\
(\text { PEG }-45 \%)\end{array}$ & Capsicum annuum & Arthrobacter spp. Bacillus spp. & [83] \\
\hline $\begin{array}{l}\text { Osmotic stress } \\
(\mathrm{PEG}-20 \%) \text { in dark }\end{array}$ & Triticum aestivum & Azospirillum & [84] \\
\hline $\begin{array}{l}\text { Osmotic stress } \\
(\mathrm{PEG}-20 \%)\end{array}$ & Triticum aestivum & Azospirillum brasilense & [85] \\
\hline Waterlogging & Lycopersicon esculentum & Enterobacter cloacae, Pseudomonas putida & [86] \\
\hline High temperature & Vitis vinifera & Burkholderia phytofirmans & \\
\hline High temperature & Solanum tuberosum & Burkholderia phytofirmans & [87] \\
\hline High temperature & Glycine max & $\begin{array}{c}\text { Aeromonas hydrophila, Serratia liquefaciens, } \\
\text { Serratia proteamaculans }\end{array}$ & [88] \\
\hline Nutrient imbalance & Zea mays & $\begin{array}{c}\text { Bacillus polymyxa, Mycobacterium phlei, } \\
\text { Pseudomonas alcaligenes }\end{array}$ & [89] \\
\hline Iron toxicity & Oryza sativa & Bacillus subtilis, B. megaterium, Bacillus spp. & {$[90,91]$} \\
\hline
\end{tabular}

Selected representation of experiments documenting a significant impact of plant-rhizobacteria on morphological, physiological, biochemical, and yield responses against environmental stresses.

\section{Plants' Root Development}

Si positively influences the root area development, diameter, volume, and length of the main root and root biomass in plants grown under adverse environmental variables [92,93]. It delays leaf fall, which enhances water use efficiency [20] and cell wall extensibility [2,94], synergistically extending water and nutrient absorption optimally to mitigate salinity and drought by activating specific plant hormones. Root traits also affect the plant growth rate and development directly. It is also well documented that indole-3-acetic acid-secreting PGPRs enhance root growth and exposed surfaces, benefitting water use efficiency and nutrient uptake [42,47] (Figures 1 and 2, Tables 1 and 2).

\section{Improvement of Photosynthesis and Plant Growth}

The photosynthetic machinery in plants is very sensitive to environmental stresses $[17,95]$. However, exogenous application of $\mathrm{Si}$ enhanced the photosynthetic capacity in various plants subjected to abiotic stresses $[2,17,29,46,96,97]$. Silicon enhanced photosynthesis, nutrient uptake, and ultimately plant growth development and biomass subjected to various stresses through increasing leaf gas exchange. Plant rhizobacteria play a crucial role in maintaining the fertility of degraded soil and improving plant performance through a wide variety of mechanisms. The mode of action of PGPRs promotes plant growth, i.e., stress tolerance in plants, easy nutrient uptake, plant growth regulators, the production of siderophores, volatile organic compounds, and protective enzymes for the protection of pest and diseases of plants [98-100]. Plant growth and development is influenced by a variety of stresses due to the soil environment, which is a major constraint for sustainable agricultural crop productivity. 


\section{Biosynthesis of Phytohormones}

Phytohormones regulate plant morphology, affecting tolerance or avoiding abiotic stress factors [101]. By directing source and sink shifts, growth, development, and the partitioning of minerals [102], phytohormones increase the capability of plants to hold up against saline stress [102,103]. Stressed plants produce 1-aminocyclopropane-1-carboxylate (ACC), a precursor of ethylene that ultimately downregulates growth and yield. However, PGPRs containing ACC deaminase activity confer improved plant growth as water uptake continues to occur even from the deeper zones of soil [1].

$\mathrm{Si}$ and PGPRs were found to be associated with the enhanced adaptation of plant hormones, i.e., auxins, gibberellins, ethylene, cytokinins, and abscisic acid (ABA) were associated with saline and drought stress $[55,93,104]$. The production of indole acetic acid (IAA) favors the root-developing structure, root tips, and area to help plants against stress [47,105]. ABA biosynthesis may also alter gene expression induced by salt stress [106]. The downregulation of jasmonic acid and upregulation of salicylic acid in soybean was found to be associated with Si [107]. These findings indicated that the PGPRs and Si can enhance stress tolerance in plants by regulating the biosynthesis of plant hormones (Figures 1 and 2, Tables 1 and 2). There is a possible influence of Si application on the activity of PGPRs and of the soil microbial consortia.

\section{Uptake and Translocation of Minerals}

All plants require adequate mineral nutrients for their growth and development [2]. Water deficit impairs nutrient availability and its uptake in the rhizosphere. Further, impaired nutrient translocation downregulates metabolic activities linked with growth and development $[17,108]$. Exogenous application of Si may balance the uptake and mobility of minerals in plants suffering from environmental stresses [20]. Sodium $\left(\mathrm{Na}^{+}\right)$may cause an excessive nutritional deficiency in plants [95], while the presence of $\mathrm{Si}$ reduces $\mathrm{Na}^{+}$uptake by decreasing membrane permeability with its improved structural durability as seen in root cells $[40,43]$. Si protects plasma membrane integrity and permeability under salinity stress in plants [109].

The availability of Si enhances the nitrogen $(\mathrm{N})$ content in plants [110], while adequate phosphorous $(\mathrm{P})$ availability ensures the presence of $\mathrm{Si}$ in various graminaceous plants $[2,18]$. The application of $\mathrm{Si}$ may also support salt stress avoidance and the distribution of few essential minerals [111,112]. Hence, the possible influence of $\mathrm{Si}$ and PGPRs may upregulate growth and plant productivity under stress by balancing the uptake of nutrients $[2,44]$.

\section{Reduction of Toxic Ions}

The downregulation of $\mathrm{Na}^{+}$entry from the rhizosphere to the cell and the enhancement of $\mathrm{Na}^{+}$ efflux into the cytosol to vacuole have been proposed as a major salt tolerance mechanism [113]. However, the balance of $\mathrm{K}^{+}$concentrations in the cell under salinity stress was found to be critical in maintaining proper cell functions [114]. Higher levels of $\mathrm{Na}^{+}$damages cells and alters vital cellular metabolic processes, leading to the generation of reactive oxygen species (ROS) and an eventual decline in the growth rate and development [115]. Hence, plants should utilize extra cell constituents to achieve a higher level of intracellular $\mathrm{K}^{+}$and a lower level of $\mathrm{Na}^{+}$ions under stress [116].

Silicon may support plant resistance to salinity by minimizing the acquisition of $\mathrm{Na}^{+}$through efflux via the $\mathrm{Na}^{+}-\mathrm{H}^{+}$channels, including salt overly sensitive $\left(\mathrm{HvSOS}_{1}\right)$ and vacuolar $\mathrm{Na}^{+} / \mathrm{H}^{+}$ antiporter $\left(\mathrm{HvNHX}_{1}\right)$ in the cell membrane and other membrane structures like the vacuolar membrane, respectively. The increasing $\mathrm{K}^{+}$entry through $\mathrm{K}^{+}-\mathrm{H}^{+}$transport proteins like HvHAK1 was found to be beneficial [117]. Further, PGPRs are described to increase the absorption of $\mathrm{K}^{+}$ions by inducing the synthesis of high-affinity ion channels, AtHKT1, in plants during salt stress with a higher $\mathrm{K}^{+} / \mathrm{Na}^{+}$ratio that extends salinity tolerance [42]. PGPR strains synthesize extracellular polymers, which associate with cations like $\mathrm{Na}^{+}$in order to limit its availability during salinity stress [118]. Si and PGPRs facilitate 
specific transport potential for $\mathrm{K}^{+}$over $\mathrm{Na}^{+}$and, hence, enhance the $\mathrm{K}^{+} / \mathrm{Na}^{+}$balance, which could be considered as an important strategy to improve the development and fruit quality during stress [44] (Figure 2, Tables 1 and 2). The presence of Si may decrease $\mathrm{Na}^{+}$and $\mathrm{Cl}^{-}$levels with an enhancement in $\mathrm{K}^{+}$translocation (or an increased $\mathrm{K}^{+} / \mathrm{Na}^{+}$ratio) in plants during salinity stress [2,44]. The exogenous application of $\mathrm{Si}$ enhances the photosynthetic characteristics in various plant species during stress [119]. It was found to reduce $\mathrm{Na}^{+}$uptake by reducing the transpiration rate. Si and PGPRs, therefore, direct specific movement of $\mathrm{K}^{+}$over $\mathrm{Na}^{+}$and, thus, enhance the $\mathrm{K}^{+} / \mathrm{Na}^{+}$ratio, which may be thought of as a major way to maintain plant development and yield against stress.

\section{In Vivo Accumulation of Compatible Solutes}

By upregulating osmotic pressures and restricting the uptake, translocation, and distribution of water, dissolved ions $\left(\mathrm{Na}^{+}\right.$and $\left.\mathrm{Cl}^{-}\right)$hinder plant morphology [116]. During stress conditions, plants need a maximum water content for development and, to some degree, a balance of the optimum water upon challenge with these stress factors through osmotic regulation $[44,120]$. A reduction in the relative water content of the leaf and water potential was observed in plants cultivated during drought. As per various experimental findings, salinity and water stress are associated with the upregulation of compatible solutes in plants, i.e., proline [121,122] and glycine betaine [123]. There are many reports that well-suited solutes may enhance plant tolerance to salt stress and water deficit conditions by (a) maintaining a high leaf water potential, (b) removing free radicals and maintaining the oxidation reduction redox potential, and (c) stabilizing membrane structures and proteins therein [44,102,124].

The improvement in the osmotic adjustment potential in response to upregulation in the osmolyte level by silicon [125] could reflect high leaf gas exchange activities with a better plant growth rate and development under stress conditions. PGPRs upregulate plant stress adaptation by enhancing the total dissolved sugar amount and storage of solutes in plants cultivated in a stressful environment [42]. Stabilizing protein-protein complexes, membranes, and osmolytes (e.g., proline, glycine betaine, amino acids, sugars (total)) reduces the negative consequences of excess ions on the antioxidant enzymatic systems $[2,46]$ as $\mathrm{Si}$ enhances tolerance to a water deficit by adjusting osmolytes in various plants $[39,46]$. These findings indicate that $\mathrm{Si}$ and PGPRs may enhance the stress tolerance in plants by adjusting the osmotic potential and maintaining and/or improving the maximum leaf water content and water uptake by plants (Figures 1 and 2, Tables 1 and 2).

\section{Response of Antioxidant Enzymes}

The application of Si may mitigate oxidative damage in plants by modulating the enzymatic and non-enzymatic constituents $[39,126]$. Generally, the negative impact of stress on plant metabolism leads to overproduction of ROS (e.g., singlet $\mathrm{O}_{2}$, hydroxyl radical, $\mathrm{H}_{2} \mathrm{O}_{2}$ and superoxide anion), which impairs various metabolic functions, causing damage to proteins, lipids, carbohydrates, and DNA $[17,20]$. ROS, in turn, may also induce a damaging effect on the plasma membrane and endo-membrane systems, and disturb general metabolic processes. The main antioxidant enzymes that have been reported with enhanced activities are catalase (CAT), superoxide dismutase (SOD), peroxidase (POD), glutathione reductase, guaiacol peroxidase (GPOD), ascorbate peroxidase (APOD), and dehydroascorbate reductase $[2,20,29]$. Salinity and water deficit may modify the activities of antioxidant enzymes [127], while Si may reduce oxidative stress by modifying antioxidative defense enzymes [126] as it induces additional support by the formation of malondialdehyde, thereby minimizing the loss of electrolytes, malondialdehyde (MDA), and immobilization and reduction of the entry of hazardous ions [39,53].

PGPR-induced antioxidant enzymes are also believed to mitigate the environmental stresses (salt and water) in plants by degrading ROS in the plant roots [13]. Hence, PGPRs and silicon application may mitigate oxidative damage in various crop/plant cultivars by upregulating ROS, SOD, POD, CAT, and APOD activities along with cysteine, glutathione, ascorbic acid, and glutathione reductase [126]. It is to be noted that Si maintains cell membrane permeability and stability under abiotic 
stresses [2] with upgraded morphological development [44] as shown in Tables 1 and 2. The above literature shows that the possible influence of $\mathrm{Si}$ and PGPRs enhances the growth rate against abiotic stresses by inducing plant synthesis of antioxidative enzymatic activities.

\section{Improvement of Plant Water Relations}

Lots of experimental studies have demonstrated that $\mathrm{Si}$ affects water-associated plant processes, mainly during environmental stresses $[17,20,39]$. Salinity- and water-stressed plants have shown a loss in water uptake, while $\mathrm{Si}$ application upgrades the water level and water use efficiency (WUE) in various plant cultivars $[50,128,129]$. The higher level of saline ions in soil results in enhanced osmotic stress, which restricts water acquisition by the plants and, eventually modulates the relative leaf water, stomatal conductance $(g s)$, leaf development area expansion, and gas exchange with a reduction in the chlorophyll content and leaf greenness that affects plant development $[2,113]$. Improvement in the plant water balance enhances the plant dry mass [130]. Si application increases $g s$ during drought to improve transpiration rates, ascribed as a positive factor to extract water from the soil [131]. Drought-challenged plants may either maintain stomatal opening to support the photosynthetic rate despite the loss of water via transpiration, or decrease the stomatal opening to retard water loss and minimize the water deficit with a loss in carboxylation [20].

In plants, the factors hindering water translocation are chiefly the roots [132]. The hydraulic conductivity of the root refers to the capacity for water acquisition, which relies on the root morphology, their permeable nature, and the applied force [133]; plants under osmotic stress primarily downregulate their root hydraulic conductivity [134]. Interestingly, $\mathrm{Si}$ is associated with enhanced root hydraulic conductivity through the improved expansion of plasma membrane aquaporins, which may partially confer an ability to enhance water uptake [129] and also decreases membrane damage [50]. PGPRs can upregulate water and fertilizer availability to inoculated plants, ensuring development and survival under unfavorable conditions [135]. PGPRs produce extracellular polymeric substances, such as polysaccharides, mucopolysaccharides, humic substances, and proteins [47] increasing the volume of soil macropores [136]. The above findings indicate that the Si and PGPRs enhance abiotic stress resistance in plants by upgrading the water balance.

\section{Induced Systemic Resistance in Plants}

PGPRs provoke systemic resistance and avoidance in plants. Inoculation of the stressed plants with PGPRs may trigger signaling pathways, which maximize the pathogen's resistance to plants [137,138], and enhanced avoidance to abiotic stresses [139]. PGPRs (e.g., Bacillus) produce volatile organic compounds (VOCs) that may participate in the induction of systemic tolerance [140]. PGPRs and Si enhanced the ability to mitigate salt tolerance in Vigna radiata [45] by regulating osmolytes with a loss in lignification in the leaves, upregulating the concentration of total soluble sugar, uptake of minerals viz., $\mathrm{K}^{+}, \mathrm{Ca}^{+}$, Si with downregulation of $\mathrm{Na}^{+}$levels similar to normal plants [45]. Si also reduces the negative effects of metal in plants by increasing the association with others. The uptake of important elements, such as zinc ( $\mathrm{Zn})$, iron (Fe), manganese $(\mathrm{Mn})$, calcium $(\mathrm{Ca})$, magnesium $(\mathrm{Mg}), \mathrm{P}$, and potassium (K), may improve their uptake [141,142]. Hence, integrated utilization of PGPRs and silicon may sustain the eco-physiological abilities of crops both under normal and stressful conditions.

\section{PGPRs and Si Mitigating Heavy Metal Toxicity}

PGPRs and Si have also been shown to mitigate the negative responses of heavy metal toxic soil [141]. Some of the known functions are shown in Figures 1 and 2 and Tables 1 and 2. Silicon has always been linked with the downregulation of the uptake and translocation of toxic ions in plants $[143,144]$. It is absorbed in plants through the formation of monosilicic acid, which is precipitated on the inner cell wall and lumen to chelate the ions through stimulation of the roots and exudates impairing the uptake of metal ions [141]. This minimizes the apoplastic movement of metals by reducing the bioavailability of free metals in the apoplast [145] as its accumulation in the endodermal layers of roots may reduce the 
mobility of metal ions [2]. Hence, through multiple functions and mechanisms, PGPRs shield the host from the phytotoxic effects of excess metal ions by altering them from bio-available to non-bioavailable pools in the soil [146].

By inducing physiological variations, such as the proliferation of roots and increasing the absorption rate of essential nutrients, plant hormone-producing PGPRs can mitigate toxic metal induced-stress and facilitate adaptation and tolerance [147]. Silicon and PGPRs alleviate the toxicity of metal ions in plants by enhancing the expression of genes resistant to heavy metal in plants. However, the combined application of PGPRs and Si to downregulate abiotic factors is not known to induce such changes.

\section{PGPRs and Si Alleviating the Adverse Effects of Nutritional Deficiency}

\subsection{Macronutrients}

Silicon and PGPRs have been shown to mitigate the harmful impacts of nutritional deficiency in plants $[13,148]$. A few well-recognized processes by which Si and PGPRs mitigate the impact of nutrient deficient soil (micro and macro elements) in plants are depicted (Figures 1 and 2, Tables 1 and 2). The use of silicon application significantly increased the $\mathrm{N}$ content in plants [2]. $\mathrm{N}$ is a limiting nutrient for natural and agricultural eco-systems [110]. PGPRs may upregulate plant $\mathrm{N}$ by enhancing symbiotic and non-symbiotic $\mathrm{N}_{2}$ fixation and the degradation of organic $\mathrm{N}$ in the soil with an enhanced plant root structure by the production of a plant hormone (IAA) and enzyme (ACC deaminase) [149-151].

Phosphorus is also an essential element frequently limiting the growth and development of plants. The function of silicon in $\mathrm{P}$ absorption by roots was regarded as the most important finding related to Si ever studied [152]. Brenchley and Maskell [153] and Fisher [154] reported that Si fertilizer enhanced the yield of barley crops, characteristically when P fertilizer was limited. Contrary to this, when P was supplied in large quantities, Si restricted P absorption with the loss of chlorophyll, probably by downregulating the rate of transpiration [155]. PGPRs contribute considerably by three main processes of the soil P cycle, viz. sorption-desorption, dissolution-precipitation, and mineralization-immobilization. In addition, phosphate-solubilizing microbes may also enhance the accessibility of $P$ through various processes like ACC deaminase, production of siderophores, synthesis of exopolysaccharides, production of IAA, and secretion of acidic substances [139].

Potassium (K) is another major nutrient with a crucial contribution in plant growth, development, and production [44]. K-solubilizing PGPRs convert $\mathrm{K}$ to bioavailable forms for plant absorption [156]. According to Mali and Aery [157], the uptake of K by the soilless system and also in the soil was found to be increased even at a reduced content of silicon dilutions through the activation of $\mathrm{H}^{+}$-ATPase (Tables 1 and 2). $\mathrm{K}$ and Si may also enhance the availability of $\mathrm{Ca} / \mathrm{Mg}$ in the rhizosphere. Si could mitigate the deficiency of $\mathrm{K}$ by upregulating the plant water status [64] and modulating the accessibility of $\mathrm{K}$ in the soil by modulating antioxidant enzyme activities [122].

\subsection{Micronutrients}

Silicon may act as a beneficial element during nutritional imbalance. Several scientists have worked on the role of Si on micronutrient deficiency $[2,158,159]$. It can alleviate the impact of micronutrients on plants $[158,160]$ by enhancing the oxidizing capacity of roots. An Si-imposed elevation in the uptake of the $\mathrm{Fe} / \mathrm{Mn}$ ratio may be due to the inducing action of $\mathrm{Si}$ in the root-growth zone linked with an improved root length through an enhancement in cell wall extension in sorghum. The enhanced concentration of biomolecules like citrate due to the amendment of Si may lead to metal transfer from the plant root to shoot system, thus reducing micronutrient deficiency-induced characteristics [148]. Si probably contributes to balance the Fe/Mn ratio [161], increasing chlorophyll formation, providing a plausible way for the induction of growth in low-Fe plants when supplemented with $\operatorname{Si}[2,162,163]$. 
Si may also alleviate $\mathrm{Zn}$ stress by avoiding the transfer to delicate organs in plants and increasing $\mathrm{Zn}^{2+}$ sorption over silicate deposits [44]. It also regulates copper $(\mathrm{Cu})$ in plants cultivated in $\mathrm{Cu}$-stressed conditions [164] by developing Si deposits on cell exterior, which enhances $\mathrm{Cu}$-binding sites $[37,148,164]$.

Iron is an important micronutrient that is lacking in plants during different conditions, viz., dryness, calcareousness, and alkalinity. IAA and siderophore produced by PGPRs may enhance Fe $[105,165]$ with an enhanced availability of $\mathrm{Mn}$ in deficient plants by affecting plant growth and root development $[166,167]$. PGPRs can enhance the micronutrient availability to plants by lowering the soil $\mathrm{pH}$ and producing chelating agents [38]. Apart from this, PGPRs can maintain $\mathrm{Cu}$ and $\mathrm{Zn}$ accessibility in soil by synthesizing various components (carboxylates and phenolic compounds) and chelators (phenolics and organics acids) and also by modulating the plant growth rate and release of root exudation molecules. The substances released from the root by the activity of PGPRs develop a complex system with $\mathrm{Mn}, \mathrm{Fe}$, and others, escaping their further precipitation [38].

PGPRs may holistically manage to mitigate the unfavorable nutrient effects of soil on plant growth and development under abiotic environmental variable/stress (Figure 1 and Tables 1 and 2). Based on the findings, it may be considered that $\mathrm{Si}$ and PGPRs minimize the nutrient deficit condition or excess availability in the host by regulating the amount of nutrients in agricultural crop plants.

\section{Conclusions and Future Prospects}

In the coming decades, land degradation will be a major threat to food security. The successful use of plant-associated bacteria in contaminant removal, soil fertility, or crop protection will rely on the capability to develop strains among the previous soil-inhabiting microbes. Plant-associated bacteria play a vital role in the restoration of degraded soils through fertility enhancement by affecting nutrient cycles as well as an improvement in the soil structure. Silicon is recognized as a non-essential element needed for plant processes with its multiple beneficial impacts on growth, development, and quality productivity of plants. The use of silicon results in promotion of the physiological fitness of plants/crops for sustainable agriculture to ensure the cultivation of food crops under climatic variables, viz., abiotic stresses. The association between plants and bacteria is well recognized for its enhanced capacity to support plant growth development and improve resistance against a myriad of environmental stressors. Hence, co-cultivation of plants with bacteria, PGPRs, and Si can mitigate abiotic stresses. Their synergic effects would definitely sustain the physiological fitness of plants for improved carboxylation linked with the plant growth rate and productivity under adverse environmental variables.

Additional demonstration is inevitable to decipher the processes by which Si and PGPRs mitigate abiotic stress responses in challenged plants. More extensive information pertaining to the basic understanding regarding the combined use of PGPRs and Si would help in the development of a strategy helpful in the mitigation of environmental stresses and would probably facilitate better elucidation of plants' responses to exposed environmental stresses.

Author Contributions: Conceptualization, K.K.V. and Y.-R.L.; methodology and data curation, K.K.V.; resources and software, K.K.V., D.-M.L., M.K.M., R.K.S. and P.S.; writing-original draft preparation, K.K.V. and V.D.R., writing-review and editing, M.S., T.M. X.-P.S. and Y.-R.L.; supervision, X.-P.S. and Y.-R.L.; project administration and funding acquisition, Y.-R.L. All authors have read and agreed to the published version of the manuscript.

Funding: This research was funded by the Guangxi R and D Program Fund, grant number GK17195100, Fund for Guangxi Innovation Teams of Modern Agriculture Technology, grant number gjnytxgxcxtd-03-01, and Fund of Guangxi Academy of Agricultural Sciences, grant number 2015 YT02.

Acknowledgments: We are thankful to the Guangxi Academy of Agricultural Sciences, Nanning, Guangxi, China for providing the necessary facilities for this study.

Conflicts of Interest: The authors have declared no conflict of interest. 


\section{References}

1. Glick, B.R. Bacteria with ACC deaminase can promote plant growth and help to feed the world. Microbiol. Res. 2014, 169, 30-39. [CrossRef] [PubMed]

2. Etesami, H.; Jeong, B.R. Silicon (Si): Review and future prospects on the action mechanisms in alleviating biotic and abiotic stresses in plants. Ecotoxicol. Environ. Saf. 2018, 147, 881-896. [CrossRef] [PubMed]

3. United Nations. 2019. World Population Prospects: Highlights. Available online: https://www. un.org/development/desa/publications/world-population-prospects-2019-highlights.html (accessed on 31 March 2020).

4. FAO. Climate Change and Food Security: A Framework Document; Food and Agricultural Organization of United Nation: Rome, Italy, 2008.

5. Sahebi, M.; Hanafi, M.M.; Akmar, A.S.N.; Rafii, M.Y.; Azizi, P.; Tengoua, F.F.; Azwa, J.N.M.; Shabanimofrad, M. Importance od silicon and mechanisms of biosilica formation in plants. BioMed Res. Int. 2015, 2015, 396010. [CrossRef]

6. Minhas, P.S.; Rane, J.; Pasala, R.K. Abiotic stresses in agriculture: An overview. In Abiotic Stress Management for Resilient Agriculture; Springer: New York, NY, USA, 2017. [CrossRef]

7. Mariani, L.; Ferrante, A. Agronomic management for enhancing plant tolerance to abiotic stresses-Drought, salinity, hypoxia, and lodging. Horticulturae 2017, 3, 52. [CrossRef]

8. Gull, A.; Lone, A.A.; Ul Islam Wani, N. Biotic and abiotic stresses in plants. Abiotic Biot. Stress Plants 2019. [CrossRef]

9. Berg, G. Plant microbe interactions promoting plant growth and health: Perspectives for controlled use of microorganisms in agriculture. Appl. Microbiol. Biotechnol. 2009, 84, 11-18. [CrossRef] [PubMed]

10. Schmidt, R.; Köberl, M.; Mostafa, A.; Ramadan, E.M.; Monschein, M.; Jensen, K.B.; Bauer, R.; Berg, G. Effects of bacterial inoculants on the indigenousmicrobiome and secondary metabolites of chamomile plants. Front Microbiol. 2014, 5, 64. [CrossRef] [PubMed]

11. Cherif, H.; Marasco, R.; Rolli, E.; Ferjani, R.; Fusi, M.; Souss, A.; Mapelli, F.; Blilou, I.; Borin, S.; Boudabous, A.; et al. Oasisdesert farming selects environment-specific date palm root endo-phytic communities and cultivable bacteria that promote resistance to drought. Environ. Microbiol. Rep. 2015, 7, 668-678. [CrossRef]

12. Kloepper, J.W.; Rodriguez, R.U.; Zehnder, G.W.; Murphy, J.F.; Sikora, E.; Fernandez, C. Plant root-bacterial interactions in biological control of soil borne diseases and potential extension to systemic and foliar diseases. Aust. Plant Pathol. 1999, 28, 21-26. [CrossRef]

13. Etesami, H.; Beattie, G.A. Plant-Microbe Interactions in Adaptation of Agricultural Crops to Abiotic Stress Conditions. In: Kumar V., Kumar M., Sharma S., Prasad R. (eds) Probiotics and Plant Health. Springer, Singapore. Probiotics Plant Health 2017, 163-200. [CrossRef]

14. Kloepper, J.W.; Leong, J.; Teintze, M.; Schroth, M.N. Enhanced plant growth by siderophores produced by plant growth promoting rhizobacteria. Nature 1980, 286, 885-886. [CrossRef]

15. Son, J.S.; Sumayo, M.; Hwang, Y.J.; Kim, B.S.; Ghim, S.Y. Screening of plant growth promoting rhizobacteria as elicitor of systemic resistance against grey leaf spot dieses in pepper. Appl. Soil Ecol. 2014, 73, 1-8. [CrossRef]

16. Lugtenberg, B.J.; Chin A-Woeng, T.F.; Bloemberg, G.V. Microbe plant interactions: Principles and mechanisms. Antonie Van Leeuwenhoek 2002, 81, 373-383. [CrossRef] [PubMed]

17. Verma, K.K.; Singh, P.; Song, X.P.; Malviya, M.K.; Singh, R.K.; Chen, G.L.; Solomon, S.; Li, Y.R. Mitigating climate change for sugarcane improvement: Role of silicon in alleviating abiotic stresses. Sugar Tech. 2020. [CrossRef]

18. Ma, J.F. Role of silicon in enhancing the resistance of plants to biotic and abiotic stresses. Soil Sci. Plant Nutr. 2004, 50, 11-18. [CrossRef]

19. Ma, J.F.; Yamaji, N. Silicon uptake and accumulation in higher plants. Trends Plant Sci. 2006, 11, $392-397$. [CrossRef]

20. Savvas, D.; Ntatsi, G. Biostimulant activity of silicon in horticulture. Scientia Hort. 2015, 196, 66-81. [CrossRef]

21. Guntzer, F.; Keller, C.; Meunier, J.D. Benefits of plant silicon for crops: A review. Agron. Sustain Dev. 2012, 32, 201-213. [CrossRef]

22. Summerfield, M.A. Silcrete in Chemical Sediments and Geomorphology; Goudie, A.S., Pye, K., Eds.; Academic Press: London, UK, 1983; pp. 59-93. 
23. Rezanka, T.; Sigler, K. Biologically active compounds of semi metals. Stud. Nat. Prod. Chem. 2008, 35, 835-921.

24. Cornelis, J.T.; Delvaux, B.; Georg, R.B.; Lucas, Y.; Ranger, J.; Opfergelt, S. Tracing the origin of dissolved silicon transferred from various soilplant systems towards rivers: A review. Biogeosciences 2011, 8, 89-112. [CrossRef]

25. Clarke, J. The occurrence and significance of biogenic opal in the regolith. Earth-Sci. Rev. 2003, 60, 175-194. [CrossRef]

26. Sommer, M.; Kaczorek, D.; Kuzyakov, Y.; Breuer, J. Silicon pools and fluxes in soils and landscapes-A review. J. Plant Nutr. Soil Sci. 2006, 169, 310-329. [CrossRef]

27. Epstein, E. Silicon: Its manifold roles in plants. Ann. Appl. Biol. 2009, 155, 155-160. [CrossRef]

28. Ma, J.F.; Yamaji, N.; Mitani-Ueno, N. Transport of silicon from roots to panicles in plants. Proc. Jpn. Acad. Ser. B Phys. Biol. Sci. 2011, 87, 377-385. [CrossRef]

29. Verma, K.K.; Liu, X.H.; Wu, K.C.; Singh, R.K.; Song, Q.Q.; Malviya, M.K.; Song, X.P.; Singh, P.; Verma, C.L.; Li, Y.R. The impact of silicon on photosynthetic and biochemical responses of sugarcane under different soil moisture levels. Silicon 2019, 12, 1355-1367. [CrossRef]

30. Verma, K.K.; Singh, R.K.; Song, Q.Q.; Singh, P.; Zhang, B.Q.; Song, X.P.; Chen, G.L.; Li, Y.R. Silicon alleviates drought stress of sugarcane plants by improving antioxidant responses. Biomed. J. Sci. Tech. Res. 2019, 17, 002957. [CrossRef]

31. Verma, K.K.; Wu, K.-C.; Singh, P.; Malviya, M.K.; Singh, R.K.; Song, X.-P.; Li, Y.R. The protective role of silicon in sugarcane under water stress: Photosynthesis and antioxidant enzymes. Biomed. J. Sci. Tech. Res. 2019, 15, 002685. [CrossRef]

32. Debona, D.; Rodrigues, F.A.; Datnoff, L.E. Silicon's role in abiotic and biotic plant stresses. Ann. Rev. Phytopathol. 2017, 55, 85-107. [CrossRef]

33. Rasool, S.; Hameed, A.; Azooz, M.; Siddiqi, T.; Ahmad, P. Salt Stress: Causes, types and responses of plants. In Ecophysiology and Responses of Plants under Salt Stress; Springer: New York, NY, USA, 2013; pp. 1-24.

34. Bodner, G.; Nakhforoosh, A.; Kaul, H.-P. Management of crop water under drought: A review. Agron. Sustain Dev. 2015, 35, 401-442. [CrossRef]

35. Nagajyoti, P.C.; Lee, K.D.; Sreekanth, T.V.M. Heavy metals, occurrence and toxicity for plants: A review. Environ. Chem. Lett. 2010, 8, 199-216. [CrossRef]

36. Compat, S.; Duffy, B.; Nowak, J.; Clément, C.; Barka, E.A. Use of plant growth promoting bacteria for biocontrol of plant diseases: Principles, mechanisms of action, and future prospects. Appl. Environ. Microbiol. 2005, 71, 4951-4959. [CrossRef]

37. Liang, Y.; Sun, W.; Zhu, Y.-G.; Christie, P. Mechanisms of silicon-mediated alleviation of abiotic stresses in higher plants: A review. Environ. Poll. 2007, 147, 422-428. [CrossRef] [PubMed]

38. Miransari, M. Soil microbes and the availability of soil nutrients. Acta Physiol. Plant. 2013, 35, 3075-3084. [CrossRef]

39. Zhu, Y.; Gong, H. Beneficial effects of silicon on salt and drought tolerance in plants. Agron. Sustain Dev. 2014, 34, 455-472. [CrossRef]

40. Exley, C. A possible mechanism of biological silicification in plants. Front. Plant Sci. 2015, 6, 853. [CrossRef]

41. Pozza, E.A.; Pozza, A.A.A.; Botelho, D.M.d.S. Silicon in plant disease control. Rev. Ceres 2015, 62, 323-331. [CrossRef]

42. Qin, Y.; Druzhinina, I.S.; Pan, X.; Yuan, Z. Microbially mediated plant salt tolerance and microbiome-based solutions for Saline agriculture. Biotechnol. Adv. 2016, 34, 1245-1259. [CrossRef]

43. Luyckx, M.; Hausman, J.-F.; Lutts, S.; Guerriero, G. Silicon and plants: Current knowledge and technological perspectives. Front Plant Sci. 2017, 8, 411. [CrossRef]

44. Etesami, H. Can interaction between silicon and plant growth promoting rhizobacteria benefits in alleviating abiotic and biotic stresses in crop plants? Agric. Ecosyst. Environ. 2018, 253, 98-112. [CrossRef]

45. Mahmood, S.; Daur, I.; Al-Solaimani, S.G.; Ahmad, S.; Madkour, M.H.; Yasir, M.; Hirt, H.; Ali, S.; Ali, Z. Plant growth promoting rhizobacteria and silicon synergistically enhance salinity tolerance of mung bean. Front. Plant Sci. 2016, 7, 876. [CrossRef]

46. Rizwan, M.; Ali, S.; Ibrahim, M.; Farid, M.; Adrees, M.; Bharwana, S.A.; Zia-ur-Rehman, M.; Qayyum, M.F.; Abbas, F. Mechanisms of silicon-mediated alleviation of drought and salt stress in plants: A review. Environ. Sci. Poll. Res. 2015, 22, 15416-15431. [CrossRef] [PubMed] 
47. Kaushal, M.; Wani, S.P. Plant-growth-promoting rhizobacteria: Drought stress alleviators to ameliorate crop production in drylands. Ann. Microbiol. 2016, 66, 35-42. [CrossRef]

48. Mahmood, S.; Daur, I.; Hussain, M.B.; Nazir, Q.; Al-Solaimani, S.G.; Ahmed, S.; Bakhashwain, A.A.; Elsafor, A.K. Silicon application and rhizobacterial inoculation regulate mung bean response to saline water irrigation. Clean Soil Air Water 2017, 45, 8. [CrossRef]

49. Safoora, D.; Cyrus, G.; Bahram, B.; Mahdi, G.; Siamak, S. Effect of silicon on growth and development of strawberry under water deficit conditions. Hort. Plant J. 2018, 4, 226-232.

50. Shi, Y.; Zhang, Y.; Han, W.; Feng, R.; Hu, Y.; Guo, J.; Gong, H. Silicon enhances water stress tolerance by improving root hydraulic conductance in Solanum lycopersicum L. Front. Plant Sci. 2016, 7, 196. [CrossRef] [PubMed]

51. Maghsoudi, K.; Emam, Y.; Ashraf, M. Influence of foliar application of silicon on chlorophyll fluorescence, photosynthetic pigments, and growth in water-stressed wheat cultivars differing in drought tolerance. Turk. J. Bot. 2015, 39, 625-634. [CrossRef]

52. Amin, M.; Ahmad, R.; Ali, A.; Hussain, I.; Mahmood, R.; Aslam, M.; Lee, D.J. Influence of silicon fertilization on maize performance under limited water supply. Silicon 2016, 10, 177-183. [CrossRef]

53. Zhu, Z.; Wei, G.; Li, J.; Qian, Q.; Yu, J. Silicon alleviates salt stress and increases antioxidant enzymes activity in leaves of salt-stressed cucumber (Cucumis sativus L.). Plant Sci. 2004, 167, 527-533. [CrossRef]

54. Flam-Shepherd, R.; Huynh, W.Q.; Coskun, D.; Hamam, A.M.; Britto, D.T.; Kronzucker, H.J. Membrane fluxes, bypass flows, and sodium stress in rice: The influence of silicon. J. Exp. Bot. 2018, 69, 1679-1692. [CrossRef]

55. Yin, L.; Wang, S.; Tanaka, K.; Fujihara, S.; Itai, A.; Den, X.; Zhang, S. Silicon mediated changes in polyamines participate in silicon-induced salt tolerance in Sorghum bicolor L. Plant Cell Environ. 2016, 39, 245-258. [CrossRef]

56. Saleh, J.; Najafi, N.; Oustan, S.; Ghasemi-Golezani, K.; Aliasghrzad, N. Silicon affects rice growth, superoxide dismutase activity and concentrations of chlorophyll and proline under different levels and sources of soil salinity. Silicon 2018, 11, 2659-2667. [CrossRef]

57. Hattori, T.; Sonobe, K.; Araki, H.; Inanaga, S.; An, P.; Morita, S. Silicon application by sorghum through the alleviation of stress-induced increase in hydraulic resistance. J. Plant Nutr. 2008, 31, 1482-1495. [CrossRef]

58. Farooq, M.A.; Detterbeck, A.; Clemens, S.; Dietz, K.J. Silicon-induced reversibility of cadmium toxicity in rice. J. Exp. Bot. 2016, 67, 3573-3585. [CrossRef] [PubMed]

59. Sanglard, L.; Martins, S.C.V.; Detmann, K.C.; Silva, P.E.M.; Lavinsky, A.O.; Silva, M.M.; Detmann, E.; Araujo, W.L.; DaMatta, M. Silicon nutrition alleviates the negative impacts of arsenic on the photosynthetic apparatus of rice leaves: An analysis of the key limitations of photosynthesis. Physiol. Plant 2014, 152, 355-366. [CrossRef] [PubMed]

60. Mateos-Naranjo, E.; Galle, A.; Florez-Sarasa, I.; Perdomo, J.A.; Galmes, J.; Ribas-Carbo, M.; Flexas, J. Assessment of the role of silicon in the $\mathrm{Cu}$-tolerance of the $\mathrm{C}_{4}$ grass Spartina densiflora. J. Plant Physiol. 2015, 178, 74-83. [CrossRef] [PubMed]

61. Rogalla, H.; Romheld, V. Role of leaf apoplast in silicon-mediated manganese tolerance of Cucumis sativus L. Plant Cell Environ. 2002, 25, 549-555. [CrossRef]

62. Maksimovic, J.D.; Mojovic, M.; Maksimovic, V.; Romheld, V.; Nikolic, M. Silicon ameliorates manganese toxicity in cucumber by decreasing hydroxyl radical accumulation in the leaf apoplast. J. Exp. Bot. 2012, 63, 2411-2420. [CrossRef]

63. Wang, Y.X.; Stass, A.; Horst, W.J. Apoplastic binding of aluminum is involved in silicon-induced amelioration of aluminum toxicity in maize. Plant Physiol. 2004, 136, 3762-3770. [CrossRef]

64. Chen, D.Q.; Cao, B.B.; Qi, L.Y.; Yin, L.N.; Wang, S.W.; Deng, X.P. Silicon-moderated K-deficiency-induced leaf chlorosis by decreasing putrescine accumulation in sorghum. Ann. Bot. 2016, 118, 305-315. [CrossRef]

65. Kaya, C.; Tuna, L.; Higgs, D. Effect of silicon on plant growth and mineral nutrition of maize grown under water-stress conditions. J. Plant Nutr. 2006, 29, 1469-1480. [CrossRef]

66. Dardanelli, M.S.; Fernández de Córdoba, F.J.; Rosario Espuny, M.; Rodríguez Carvajal, M.A.; Soria Díaz, M.E.; Gil Serrano, A.M.; Okon, Y.; Megías, M. Effect of Azospirillum brasilense coinoculated with Rhizobium on Phaseolus vulgaris flavonoids and Nod factor production under salt stress. Soil Biol. Biochem. 2008, 40, 2713-2721. [CrossRef] 
67. Nadeem, S.M.; Zahir, Z.A.; Naveed, M.; Arshad, M. Preliminary investigations on inducing salt tolerance in maize through inoculation with rhizobacteria containing ACC deaminase activity. Can. J. Microbiol. 2007, 53, 1141-1149. [CrossRef] [PubMed]

68. Saravanakumar, D.; Samiyappan, R. ACC deaminase from Pseudomonas fluorescens mediated saline resistance in groundnut (Arachis hypogaea) plants. J. App. Microbiol. 2007, 102, 1283-1292. [CrossRef] [PubMed]

69. Barassi, C.A.; Ayrault, G.; Creus, C.M.; Sueldo, R.J.; Sobrero, M.T. Seed inoculation with Azospirillum mitigates $\mathrm{NaCl}$ effects on lettuce. Sci. Hortic. 2006, 109, 8-14. [CrossRef]

70. Mayak, S.; Tirosh, T.; Glick, B.R. Plant growth-promoting bacteria confer resistance in tomato plants to salt stress. Plant Physiol. Biochem. 2004, 42, 565-572. [CrossRef]

71. Ashraf, M.; Hasnain, S.; Berge, O.; Mahmood, T. Inoculating wheat seedlings with exopolysaccharide-producing bacteria restricts sodium uptake and stimulates plant growth under salt stress. Biol. Fertil. Soils 2004, 40, 157-162. [CrossRef]

72. Hamdia, A.B.E.; Shaddad, M.A.K.; Doaa, M.M. Mechanisms of salt tolerance and interactive effects of Azospirillum brasilense inoculation on maize cultivars grown under salt stress conditions. Plant Growth Regul. 2004, 44, 165-174. [CrossRef]

73. Hamaoui, B.; Abbadi, J.M.; Burdman, S.; Rashid, A.; Sarig, S.; Okon, Y. Effects of inoculation with Azospirillum brasilense on chickpeas (Cicer arietinum) and faba beans (Vicia faba) under different growth conditions. Agronomie 2001, 2, 553-560. [CrossRef]

74. El-Akhal, M.R.; Rincon, A.; Coba de la Pena, T.; Lucas, M.M.; El Mourabit, N.; Barrijal, S.; Pueyo, J.J. Effects of salt stress and rhizobial inoculation on growth and nitrogen fixation of three peanut cultivars. Plant Biol. 2013, 15, 415-421. [CrossRef]

75. Yao, L.; Wu, Z.; Zheng, Y. Growth promotion and protection against salt stress by Pseudomonas putida Rs-198 on cotton. Eur. J. Soil Biol. 2010, 46, 49-54. [CrossRef]

76. Mayak, S.; Tirosh, T.; Glick, B.R. Plant growth-promoting bacteria that confer resistance to water stress in tomatoes and peppers. Plant Sci. 2004, 166, 525-530. [CrossRef]

77. Ahmad, M.; Zahir, Z.A.; Khalid, M. Efficacy of Rhizobium and Pseudomonas strains to improve physiology, ionic balance and quality of mung bean under salt-affected conditions on farmer's fields. Plant Physiol. Biochem. 2013, 63, 170-176. [CrossRef] [PubMed]

78. Creus, C.M.; Sueldo, R.J.; Barassi, C.A. Water relations and yield in Azospirillum-inoculated wheat exposed to drought in the field. Can. J. Bot. 2004, 82, 273-281. [CrossRef]

79. Casanovas, E.M.; Barassi, C.A.; Sueldo, R.J. Azospirillum inoculation mitigates water stress effects in maize seedlings. Cereal Res. Commun. 2002, 30, 343-350. [CrossRef]

80. German, M.A.; Burdman, S.; Okon, Y.; Kigel, J. Effects of Azospirillum brasilense on root morphology of common bean (Phaseolus vulgaris L.) under different water regimes. Biol. Fertil. Soils 2000, 32, 259-264. [CrossRef]

81. Belimov, A.A.; Dodd, I.C.; Hontzeas, N.; Theobald, J.C.; Safronova, V.I.; Davies, W.J. Rhizosphere bacteria containing 1-aminocyclopropane-1-carboxylate deaminase increase yield of plants grown in drying soil via both local and systemic hormone signalling. New Phytol. 2009, 181, 413-423. [CrossRef]

82. Arkhipova, T.N.; Prinsen, E.; Veselov, S.U.; Martinenko, E.V.; Melentiev, A.I.; Kudoyarova, G.R. Cytokinin producing bacteria enhance plant growth in drying soil. Plant Soil 2007, 292, 305-315. [CrossRef]

83. Sziderics, A.H.; Rasche, F.; Trognitz, F.; Sessitsch, A.; Wilhelm, E. Bacterial endophytes contribute to abiotic stress adaptation in pepper plants (Capsicum annuum L.). Can. J. Microbiol. 2007, 53, 1195-1202. [CrossRef]

84. Pereyra, M.A.; Zalazar, C.A.; Barassi, C.A. Root phospholipids in Azospirillum-inoculated wheat seedlings exposed to water stress. Plant Physiol. Biochem. 2006, 44, 873-879. [CrossRef]

85. Creus, C.M.; Sueldo, R.J.; Barassi, C.A. Water relations in Azospirillum-inoculated wheat seedlings under osmotic stress. Can. J. Bot. Revue Canadienne De Botanique 1998, 76, 238-244. [CrossRef]

86. Grichko, V.P.; Glick, B.R. Amelioration of flooding stress byACC deaminase-containing plant growth-promoting bacteria. Plant Physiol. Biochem. 2001, 39, 11-17. [CrossRef]

87. Bensalim, S.; Nowak, J.; Asiedu, S.K. A plant growth promoting rhizobacterium and temperature effects on performance of 18 clones of potato. Am. J Potato Res. 1998, 75, 145-152. [CrossRef]

88. Zhang, F.; Dashti, N.; Hynes, R.K.; Smith, D.L. Plant growth promoting rhizobacteria and soybean [Glycine $\max (\mathrm{L}$.$) Merr] growth and physiology at suboptimal root zone temperatures. Ann. Bot. 1997, 79, 243-249$. [CrossRef] 
89. Egamberdiyeva, D. The effect of plant growth promoting bacteria on growth and nutrient uptake of maize in two different soils. App. Soil Ecol. 2007, 36, 184-189. [CrossRef]

90. Asch, F.; Padham, J.L. Root associated bacteria suppress symptoms of iron toxicity in lowland rice. In The Global Food E Product Chain-Dynamics, Innovations, Conflicts, Strategies; Tielkes, E., Hülsebusch, C., Häuser, I., Deininger, A., Becker, K., Eds.; MDD GmbH: Stuttgart, Germany, 2005; p. 276.

91. Terré, S.; Asch, F.; Padham, J.; Sikora, R.A.; Becker, M. Influence of root zone bacteria on root iron plaque formation in rice subjected to iron toxicity. In Proceedings of the Conference on Utilisation of Diversity in Land Use Systems: Sustainable and Organic Approaches to Meet Human Needs, Tropentag, Witzenhausen, Germany, 8 October 2007.

92. Lee, S.K.; Sohn, E.Y.; Hamayun, M.; Yoon, J.Y.; Lee, I.J. Effect of silicon on growth and salinity stress of soybean plant grown under hydroponic system. Agrofor. Syst. 2010, 80, 333-340. [CrossRef]

93. Kim, Y.H.; Khan, A.L.; Waqas, M.; Shim, J.K.; Kim, D.H.; Lee, K.Y.; Lee, I.J. Silicon application to rice root zone influenced the phytohormonal and antioxidant responses under salinity stress. J. Plant Growth Regul. 2014, 33, 137-149. [CrossRef]

94. Hameed, A.; Sheikh, M.A.; Jamil, A.; Basra, S.M.A. Seed priming with sodium silicate enhances seed germination and seedling growth in wheat (Triticum aestivum L.) under water deficit stress induced by polyethylene glycol. Pak. J. Life Soc. Sci. 2013, 11, 19-24.

95. Gupta, B.; Huang, B. Mechanism of salinity tolerance in plants: Physiological, biochemical, and molecular characterization. Int. J. Genom. 2014, 2014, 701596. [CrossRef]

96. Gong, H.; Chen, K. The regulatory role of silicon on water relations, photosynthetic gas exchange, and carboxylation activities of wheat leaves in field drought conditions. Acta Physiol. Plant. 2012, 34, 1589-1594. [CrossRef]

97. Liu, P.; Yin, L.; Wang, S.; Zhang, M.; Deng, X.; Zhang, S.; Tanaka, K. Enhanced root hydraulic conductance by aquaporin regulation accounts for silicon alleviated salt-induced osmotic stress in Sorghum Bicolor L. Environ. Exp. Bot. 2015, 111, 42-51. [CrossRef]

98. Choudhary, D.K.; Sharma, K.P.; Gaur, R.K. Biotechnological perspectives of microbes in agro-ecosystems. Biotechnol. Lett. 2011, 33, 1905-1910. [CrossRef] [PubMed]

99. García-Fraile, P.; Menéndez, E.; Rivas, R. Role of bacterial biofertilizers in agriculture and forestry. AIMS Bioeng. 2015, 2, 183-205. [CrossRef]

100. Vejan, P.; Abdullah, R.; Khadiran, T.; Ismail, S.; Boyce, A.N. Role of plant growth promoting rhizobacteria in agricultural sustainability-A review. Molecules 2016, 21, 573. [CrossRef] [PubMed]

101. Ryu, H.; Cho, Y.-G. Plant hormones in salt stress tolerance. J. Plant Biol. 2015, 58, 147-155. [CrossRef]

102. Fahad, S.; Hussain, S.; Matloob, A.; Khan, F.A.; Khaliq, A.; Saud, S.; Hassan, S.; Shan, D.; Khan, F.; Ullah, N. Phytohormones and plant responses to salinity stress: A review. Plant Growth Regul. 2015, 75, 391-404. [CrossRef]

103. Iqbal, N.; Umar, S.; Khan, N.A.; Khan, M.I.R. A new perspective of phytohormones in salinity tolerance: Regulation of proline metabolism. Environ. Exp. Bot. 2014, 100, 34-42. [CrossRef]

104. Tsukanova, K.A.; Chebotar, V.; Meyer, J.J.M.; Bibikova, T.N. Effect of plant growth-promoting Rhizobacteria on plant hormone homeostasis. S. Afr. J. Bot. 2017, 113, 91-102. [CrossRef]

105. Etesami, H.; Alikhani, H.A.; Hosseini, H.M. Indole-3-acetic acid (IAA) production trait, a useful screening to select endophytic and rhizosphere competent bacteria for rice growth promoting agents. MethodsX 2015, 2, 72-78. [CrossRef]

106. Wang, Y.; Mopper, S.; Hasenstein, K.H. Effects of salinity on endogenous ABA, IAA, JA, and SA in Iris hexagona. J. Chem. Ecol. 2001, 27, 327-342. [CrossRef]

107. Hamayun, M.; Sohn, E.-Y.; Khan, S.A.; Shinwari, Z.K.; Khan, A.L.; Lee, I.-J. Silicon alleviates the adverse effects of salinity and drought stress on growth and endogenous plant growth hormones of soybean (Glycine $\max$ L.). Pak. J. Bot. 2010, 42, 1713-1722.

108. Farooq, M.; Wahid, A.; Kobayashi, N.; Fujita, D.; Basra, S. Plant drought stress: Effects, mechanisms and management. In Sustainable Agriculture; Springer: Amsterdam, The Netherlands, 2009; pp. 153-188.

109. Liang, Y.; Zhang, W.; Chen, Q.; Ding, R. Effects of silicon on $\mathrm{H}^{+}$-ATPase and $\mathrm{H}^{+}$- PPase activity, fatty acid composition and fluidity of tonoplast vesicles from roots of salt-stressed barley (Hordeum vulgare L.). Environ. Exp. Bot. 2005, 53, 29-37. [CrossRef] 
110. Huang, X.; Zhang, Z.; Ke, Y.; Xiao, C.; Peng, Z.; Wu, L.; Li, Y.; Jian, H.; Cen, J.; Zhang, Y. Effects of silicate fertilizer on nutrition of leaves, yield and sugar of sugarcanes. Trop. Subtrop. Soil Sci. 1997, 6, 242-246.

111. Soundararajan, P.; Manivannan, A.; Jeong, B.R. Regulatory mechanisms by silicon to overcome the salinity-induced imbalance of essential nutrient elements. In Silicon in Plants: Advances and Future Prospects; CRC Press: Boca Raton, FL, USA, 2016; pp. 47-66.

112. Olanrewaju, O.S.; Glick, B.R.; Babalola, O.O. Mechanisms of action of plant growth promoting bacteria. World J. Microbiol. Biotechnol. 2017, 33, 197. [CrossRef]

113. Munns, R.; Tester, M. Mechanisms of salinity tolerance. Annu. Rev. Plant Biol. 2008, 59, 651-681. [CrossRef]

114. Kronzucker, H.J.; Coskun, D.; Schulze, L.M.; Wong, J.R.; Britto, D.T. Sodium as nutrient and toxicant. Plant Soil 2013, 369, 1-23. [CrossRef]

115. Mahajan, S.; Tuteja, N. Cold, salinity and drought stresses: An overview. Arch. Biochem. Biophys. 2005, 444, 139-158. [CrossRef]

116. Hu, Y.; Schmidhalter, U. Drought and salinity: A comparison of their effects on mineral nutrition of plants. J. Plant Nutr. Soil Sci. 2005, 168, 541-549. [CrossRef]

117. Coskun, D.; Britto, D.T.; Huynh, W.Q.; Kronzucker, H.J. The role of silicon in higher plants under salinity and drought stress. Front. Plant Sci. 2016, 7, 1072. [CrossRef]

118. Geddie, J.L.; Sutherland, I.W. Uptake of metals by bacterial polysaccharides. J. Appl. Bacteriol. 1993, 74, 467-472. [CrossRef]

119. Xie, Z.; Song, R.; Shao, H.; Song, F.; Xu, H.; Lu, Y. Silicon improves maize photosynthesis in saline-alkaline soils. Sci. World J. 2015, 2015, 245072. [CrossRef]

120. Osakabe, Y.; Osakabe, K.; Shinozaki, K.; Tran, L.-S.P. Response of plants to water stress. Front. Plant Sci. 2014, 5, 86. [CrossRef] [PubMed]

121. Gzik, A. Accumulation of proline and pattern of $\alpha$-amino acids in sugar beet plants in response to osmotic, water and salt stress. Environ. Exp. Bot. 1996, 36, 29-38. [CrossRef]

122. Pei, Z.; Ming, D.; Liu, D.; Wan, G.; Geng, X.; Gong, H.; Zhou, W. Silicon improves the tolerance to water-deficit stress induced by polyethylene glycol in wheat (Triticum aestivum L.) seedlings. J. Plant Growth Regul. 2010, 29, 106-115. [CrossRef]

123. Mansour, M.M.F. Protection of plasma membrane of onion epidermal cells by glycinebetaine and proline against $\mathrm{NaCl}$ stress. Plant Physiol. Biochem. 1998, 36, 767-772. [CrossRef]

124. Kohler, J.; Hernández, J.A.; Caravaca, F.; Roldán, A. Induction of antioxidant enzymes is involved in the greater effectiveness of a PGPR versus AM fungi with respect to increasing the tolerance of lettuce to severe salt stress. Environ. Exp. Bot. 2009, 65, 245-252. [CrossRef]

125. Pereira, T.S.; da Silva Lobato, A.K.; Tan, D.K.Y.; da Costa, D.V.; Uchôa, E.B.; do Nascimento Ferreira, R.; dos Santos Pereira, E.; Ávila, F.W.; Marques, D.J.; Guedes, E.M.S. Positive interference of silicon on water relations, nitrogen metabolism, and osmotic adjustment in two pepper (Capsicum annuum) cultivars under water deficit. Aust. J. Crop. Sci. 2013, 7, 1064.

126. Kim, Y.-H.; Khan, A.L.; Waqas, M.; Lee, I.-J. Silicon regulates antioxidant activities of crop plants under abiotic-induced oxidative stress: A review. Front. Plant Sci. 2017, 8, 510. [CrossRef]

127. Demidchik, V. Reactive oxygen species and oxidative stress in plants. In Plant Stress Physiology; Shabala, S., Ed.; CAB International: Wallingford, UK; Oxford, UK, 2012; pp. 24-58.

128. Gao, X.; Zou, C.; Wang, L.; Zhang, F. Silicon decreases transpiration rate and conductance from stomata of maize plants. J. Plant. Nutr. 2006, 29, 1637-1647. [CrossRef]

129. Zhu, Y.-X.; Xu, X.-B.; Hu, Y.-H.; Han, W.-H.; Yin, J.-L.; Li, H.-L.; Gong, H.-J. Silicon improves salt tolerance by increasing root water uptake in Cucumis sativus L. Plant Cell Rep. 2015, 34, 1629-1646. [CrossRef]

130. Gong, H.J.; Chen, K.M.; Zhao, Z.G.; Chen, G.C.; Zhou, W.J. Effects of silicon on defense of wheat against oxidative stress under drought at different developmental stages. Biol. Plant. 2008, 52, 592-596. [CrossRef]

131. Hattori, T.; Inanaga, S.; Araki, H.; An, P.; Morita, S.; Luxova, M.; Lux, A. Application of silicon enhanced drought tolerance in Sorghum bicolor. Physiol. Plant. 2005, 123, 459-466. [CrossRef]

132. Rubio-Asensio, J.S.; López-Berenguer, C.; García-de la Garma, J.; Burger, M.; Bloom, A.J. Root strategies for nitrate assimilation. In Root Engineering; Springer: New York, NY, USA, 2014; pp. 251-267.

133. Sutka, M.; Li, G.; Boudet, J.; Boursiac, Y.; Doumas, P.; Maurel, C. Natural variation of root hydraulics in Arabidopsis grown in normal and salt-stressed conditions. Plant Physiol. 2011, 155, 1264-1267. [CrossRef] [PubMed] 
134. Boursiac, Y.; Chen, S.; Luu, D.-T.; Sorieul, M.; van den Dries, N.; Maurel, C. Early effects of salinity on water transport in Arabidopsis roots. Molecular and cellular features of aquaporin expression. Plant Physiol. 2005, 139, 790-805. [CrossRef] [PubMed]

135. Vardharajula, S.; Zulfikar Ali, S.; Grover, M.; Reddy, G.; Bandi, V. Drought-tolerant plant growth promoting Bacillus spp.: Effect on growth, osmolytes, and antioxidant status of maize under drought stress. J. Plant Interact. 2011, 6, 1-14. [CrossRef]

136. Upadhyay, S.K.; Singh, J.S.; Singh, D.P. Exopolysaccharide-producing plant growth-promoting rhizobacteria under salinity condition. Pedosphere 2011, 21, 214-222. [CrossRef]

137. Van Loon, L.C.; Bakker, P.; Pieterse, C.M.J. Systemic resistance induced by rhizosphere bacteria. Annu. Rev. Phytopathol. 1998, 36, 453-483. [CrossRef]

138. Egamberdieva, D.; Lugtenberg, B. Use of plant growth-promoting rhizobacteria to alleviate salinity stress in plants. Use Microb. Allev. Soil Stress 2014, 1, 73-96.

139. Sharma, S.B.; Sayyed, R.Z.; Trivedi, M.H.; Gobi, T.A. Phosphate solubilizing microbes: Sustainable approach for managing phosphorus deficiency in agricultural soils. Springer Plus 2013, 2, 587. [CrossRef]

140. Ryu, C.-M.; Farag, M.A.; Hu, C.-H.; Reddy, M.S.; Kloepper, J.W.; Paré, P.W. Bacterial volatiles induce systemic resistance in Arabidopsis. Plant Physiol. 2004, 134, 1017-1026. [CrossRef]

141. Adrees, M.; Ali, S.; Rizwan, M.; Zia-ur-Rehman, M.; Ibrahim, M.; Abbas, F.; Farid, M.; Qayyum, M.F.; Irshad, M.K. Mechanisms of silicon-mediated alleviation of heavy metal toxicity in plants: A review. Ecotoxicol. Environ. Saf. 2015, 119, 186-197. [CrossRef]

142. Keller, C.; Rizwan, M.; Davidian, J.-C.; Pokrovsky, O.; Bovet, N.; Chaurand, P.; Meunier, J.-D. Effect of silicon on wheat seedlings (Triticum turgidum L.) grown in hydroponics and exposed to 0 to $30 \mu \mathrm{M} \mathrm{Cu}$. Planta 2015, 241, 847-860. [CrossRef] [PubMed]

143. Anwaar, S.A.; Ali, S.; Ali, S.; Ishaque, W.; Farid, M.; Farooq, M.A.; Najeeb, U.; Abbas, F.; Sharif, M. Silicon (Si) alleviates cotton (Gossypium hirsutum L.) from zinc $(\mathrm{Zn})$ toxicity stress by limiting $\mathrm{Zn}$ uptake and oxidative damage. Environ. Sci. Poll. Res. 2015, 22, 3441-3450. [CrossRef] [PubMed]

144. Tripathi, D.K.; Singh, V.P.; Prasad, S.M.; Chauhan, D.K.; Dubey, N.K.; Rai, A.K. Silicon-mediated alleviation of $\mathrm{Cr}$ (VI) toxicity in wheat seedlings as evidenced by chlorophyll florescence, laser induced breakdown spectroscopy and anatomical changes. Ecotoxicol. Environ. Saf. 2015, 113, 133-144. [CrossRef] [PubMed]

145. Iwasaki, K.; Maier, P.; Fecht, M.; Horst, W.J. Leaf apoplastic silicon enhances manganese tolerance of cowpea (Vigna unguiculata). J. Plant Physiol. 2002, 159, 167-173. [CrossRef]

146. Sessitsch, A.; Kuffner, M.; Kidd, P.; Vangronsveld, J.; Wenzel, W.W.; Fallmann, K.; Puschenreiter, M. The role of plant-associated bacteria in the mobilization and phytoextraction of trace elements in contaminated soils. Soil Biol. Biochem. 2013, 60, 182-194. [CrossRef]

147. Chmielowska-Bak, J.; Gzyl, J.; Rucinska-Sobkowiak, R.; Arasimowicz-Jelonek, M.; Deckert, J. The new insights into cadmium sensing. Front. Plant Sci. 2014, 5, 245.

148. Hernandez-Apaolaza, L. Can silicon partially alleviate micronutrient deficiency in plants? A review. Planta 2014, 240, 447-458. [CrossRef]

149. Glick, B.R. Plant growth-promoting bacteria: Mechanisms and applications. Scientifica 2012, 5, 963401. [CrossRef]

150. Etesami, H.; Alikhani, H.A. Co-inoculation with endophytic and rhizosphere bacteria allows reduced application rates of $\mathrm{N}$-fertilizer for rice plant. Rhizosphere 2016, 2, 5-12. [CrossRef]

151. Etesami, H.; Alikhani, H.A. Rhizosphere and endorhiza of oilseed rape (Brassica napus L.) plant harbor bacteria with multifaceted beneficial effects. Biol. Control 2016, 94, 11-24. [CrossRef]

152. Eneji, A.E.; Inanaga, S.; Muranaka, S.; Li, J.; Hattori, T.; An, P.; Tsuji, W. Growth and nutrient use in four grasses under drought stress as mediated by silicon fertilizers. J. Plant Nutr. 2008, 31, 355-365. [CrossRef]

153. Brenchley, W.E.; Maskell, E.J. The inter-relation between silicon and other elements in plant nutrition. Ann. Appl. Biol. 1927, 14, 45-82. [CrossRef]

154. Fisher, R.A. A preliminary note on the effect of sodium silicate in increasing the yield of barley. J. Agric. Sci. 1929, 19, 132-139. [CrossRef]

155. Ma, J.F.; Miyake, Y.; Takahashi, E. Silicon as a beneficial element for crop plants. In Silicon in Agriculture; Datnoff, L.E., Snyder, G.H., Korndorfer, G.H., Eds.; Elsevier: Amsterdam, The Netherlands, 2001; Volume 8, pp. 17-39. 
156. Meena, V.S.; Maurya, B.R.; Verma, J.P. Does a rhizospheric microorganism enhance K+ availability in agricultural soils? Microbiol. Res. 2014, 169, 337-347. [CrossRef] [PubMed]

157. Mali, M.; Aery, N.C. Influence of silicon on growth, relative water contents and uptake of silicon, calcium and potassium in wheat grown in nutrient solution. J. Plant Nutr. 2008, 31, 1867-1876. [CrossRef]

158. Pavlovic, J.; Samardzic, J.; Maksimović, V.; Timotijevic, G.; Stevic, N.; Laursen, K.H.; Hansen, T.H.; Husted, S.; Schjoerring, J.K.; Liang, Y. Silicon alleviates iron deficiency in cucumber by promoting mobilization of iron in the root apoplast. New Phytol. 2013, 198, 1096-1107. [CrossRef]

159. Bityutskii, N.; Pavlovic, J.; Yakkonen, K.; Maksimovic, V.; Nikolic, M. Contrasting effect of silicon on iron, zinc and manganese status and accumulation of metal-mobilizing compounds in micronutrient-deficient cucumber. Plant Physiol. Biochem. 2014, 74, 205-211. [CrossRef]

160. Maksimovic, J.D.; Bogdanovic, J.; Maksimovic, V.; Nikolic, M. Siliconmodulates the metabolism and utilization of phenolic compounds incucumber (Cucumis sativus L.) grown at excess manganese. J. Plant Nutr. Soil Sci. 2007, 170, 739-744. [CrossRef]

161. Pich, A.; Scholz, G.; Stephan, U.W. Iron-dependent changes of heavy metals, nicotianamine, and citrate in different plant organs and in the xylem exudate of two tomato genotypes. Nicotianamine as possible copper translocator. Plant Soil 1994, 165, 189-196. [CrossRef]

162. Wallace, A. Participation of silicon in cation-anion balance as a possible mechanism for aluminum and iron tolerance in some Gramineae. J. Plant Nutr. 1993, 16, 547-553. [CrossRef]

163. Gonzalo, M.J.; Lucena, J.J.; Hernández-Apaolaza, L. Effect of silicon addition on soybean (Glycine max) and cucumber (Cucumis sativus) plants grown under iron deficiency. Plant Physiol. Biochem. 2013, 70, 455-461. [CrossRef] [PubMed]

164. Frantz, J.M.; Khandekar, S.; Leisner, S. Silicon differentially influences copper toxicity response in silicon-accumulator and non-accumulator species. J. Am. Soc. Hortic. Sci. 2011, 136, 329-338. [CrossRef]

165. Ramos-Solano, B.; García, J.A.L.; Garcia-Villaraco, A.; Algar, E.; Garcia-Cristobal, J.; Mañero, F.J.G. Siderophore and chitinase producing isolates from the rhizosphere of Nicotiana glauca Graham enhance growth and induce systemic resistance in Solanum lycopersicum L. Plant Soil 2010, 334, 189-197. [CrossRef]

166. Osorio Vega, N.W. A review on beneficial effects of rhizosphere bacteria on soil nutrient availability and plant nutrient uptake. Rev. Fac. Nac. Agron. Medellin 2007, 60, 3621-3643.

167. Dutta, S.; Podile, A.R. Plant growth promoting rhizobacteria (PGPR): The bugs to debug the root zone. Crit. Rev. Microbiol. 2010, 36, 232-244. [CrossRef] 